Check for updates

Cite this: Chem. Sci., 2019, 10, 1117

¿ All publication charges for this article have been paid for by the Royal Society of Chemistry

Received 28th June 2018

Accepted 1st November 2018

DOI: $10.1039 / \mathrm{c} 8 \mathrm{sc} 02864 \mathrm{~h}$

rsc.li/chemical-science

\section{A low-valent dinuclear ruthenium diazadiene complex catalyzes the oxidation of dihydrogen and reversible hydrogenation of quinones $\uparrow$}

\author{
Xiuxiu Yang, ${ }^{a}$ Thomas L. Gianetti, (D) *ab Michael D. Wörle, ${ }^{a}$ Nicolaas P. van Leest, (D) \\ Bas de Bruin (D) ${ }^{c}$ and Hansjörg Grützmacher (D) *a
}

\begin{abstract}
The dinuclear ruthenium complex $\left[\mathrm{Ru}_{2} \mathrm{H}(\mu-\mathrm{H})\left(\mathrm{Me}_{2} \mathrm{dad}\right)(\mathrm{dbcot})_{2}\right]$ contains a 1,4-dimethyl-diazabuta-1,3diene ( $\left.\mathrm{Me}_{2} \mathrm{dad}\right)$ as a non-innocent bridging ligand between the metal centers to give a $\left[\mathrm{Ru}_{2}\left(\mathrm{Me}_{2} \mathrm{dad}\right)\right]$ core. In addition, each ruthenium is bound to one dibenzo[a,e]cyclooctatetraene (dbcot) ligand. This Ru dimer converts $\mathrm{H}_{2}$ to protons and electrons. It also catalyzes reversibly under mild conditions the selective hydrogenation of vitamins $\mathrm{K}_{2}$ and $\mathrm{K}_{3}$ to their corresponding hydroquinone equivalents without affecting the $\mathrm{C}=\mathrm{C}$ double bonds. Mechanistic studies suggest that the $\left[\mathrm{Ru}_{2}\left(\mathrm{Me}_{2} \mathrm{dad}\right)\right]$ moiety, like hydrogenases, reacts with $\mathrm{H}_{2}$ and releases electrons and protons stepwise.
\end{abstract}

Hydrogenase enzymes are the most efficient biological catalysts for the mutual interconversion of hydrogen to protons and electrons, $\mathrm{H}_{2} \leftrightarrows \mathrm{H}^{+}+\mathrm{H}^{-} \cdot{ }^{1-4}$ A detailed understanding of the mechanisms of these reactions is necessary for the development of efficient artificial catalytic systems for the use of $\mathrm{H}_{2}$ as a renewable energy source. ${ }^{5}$ Currently, there are three classes of hydrogenases known which either contain a bimetallic core, $[\mathrm{Fe}, \mathrm{Fe}]$ or $[\mathrm{Fe}, \mathrm{Ni}]$, or a single $\mathrm{Fe}$ center as active sites. ${ }^{3,4}$ Intensive spectroscopic investigations, including the determination of the structures of several hydrogenases by single-crystal X-ray diffraction methods, ${ }^{6-8}$ allowed extraction of the essential features needed for activity: (i) redox active metal centers; (ii) an electron reservoir; (iii) a cooperating ligand ${ }^{9-11}$ participating reversibly in the heterolytic cleavage/formation of $\mathrm{H}_{2}$; and (iv) a free coordination site for substrate binding (see a simplified sketch of the active [Fe,Fe] core at the top of Fig. 1).

All hydrogenases contain $\mathrm{CO}$ and some $\mathrm{CN}$ as archetypical $\sigma$ donor $/ \pi$-acceptor ligands that keep iron in a low spin state and link these enzymes to classical organometallic chemistry. Consequently, the synthesis of hydrogenase model complexes is an intensively investigated topic of organometallic chemistry and some recent relevant examples $\mathbf{A}-\mathbf{G}$ are shown in Fig. 1. Complexes $\mathbf{A}$ and $\mathbf{B}$ employ redox non-innocent ligands like

\footnotetext{
${ }^{a}$ Department of Chemistry and Applied Biosciences, ETH Zürich, Vladimir-Prelog-Weg 1, 8093 Zürich, Switzerland. E-mail: hgruetzmacher@ethz.ch

${ }^{b}$ Department of Chemistry and Biochemistry, The University of Arizona, Tucson, Arizona 85721, USA. E-mail: tgianetti@email.arizona.edu

${ }^{c}$ Van't Hoff Institute for Molecular Sciences (HIMS), University of Amsterdam (UvA), Science Park 904, 1098 XH Amsterdam, The Netherlands

$\dagger$ Electronic supplementary information (ESI) available. CCDC 1535510, 1535543, 1535559,1535561 and 1852336 . For ESI and crystallographic data in CIF or other electronic format see DOI: $10.1039 / \mathrm{c} 8 \mathrm{sc} 02864 \mathrm{~h}$
}

bipyridine ${ }^{12}$ or phosphole ${ }^{13}$ in order to mimic $\mathrm{Fe}_{4} \mathrm{~S}_{4}$ ferredoxines as ubiquitous electron reservoirs in enzymes. ${ }^{14,15}$ Both complexes, A and $\mathbf{B}$, are active electrocatalysts for the production of $\mathrm{H}_{2}$ from acidic media. To date, the closest model to natural $[\mathrm{Fe}, \mathrm{Fe}]$ hydrogenases is complex $\mathbf{C}$, which can catalyze the oxidation of $\mathrm{H}_{2}$ to $\mathrm{H}^{+}$in the presence of an oxidant and a base. ${ }^{16}$ The discovery that basic sites in a chelating diphosphane ligand greatly enhance the efficiency of heterolytic $\mathrm{H}_{2}$ splitting and the electrochemical oxidation of $\mathrm{H}_{2}{ }^{17,18}$ has led to the development of iron or nickel complexes like $\mathbf{D}$ as functional hydrogenase models which achieve truly impressive turnover frequencies (TOFs) of up to $100000 \mathrm{~s}^{-1}$ for the electrocatalytic production of $\mathrm{H}_{2} \cdot{ }^{19-23}$ When tethered to conducting support materials, derivatives of $\mathbf{D}$ allow fabrication of membrane-electrode assemblies at which $\mathrm{H}_{2}$ is produced at a very low overpotential. ${ }^{18}$ The structural and functional model $\mathbf{E}$ for [Ni,Fe] hydrogenase was reported, which likewise generates $\mathrm{H}_{2}$ from mildly acidic solutions with high rates. ${ }^{24}$ The mononuclear iron model complex $\mathbf{F}$ in combination with an apoenzyme was used to prepare an [Fe] hydrogenase model..$^{25}$ Remarkably, this semiartificial enzyme, like its natural counterpart, is able to reversibly hydrogenate methylene tetrahydromethanopterin. Due to the enhanced stability of $\mathrm{Ru}$ hydrides, the replacement of Fe with Ru in artificial enzymes has also been investigated. ${ }^{26-29}$ Several dinuclear ruthenium complexes were proposed as hydrogenase mimics. ${ }^{30-32}$ For example, Rauchfuss et al. achieved the photochemical addition of $\mathrm{H}_{2}$ across the $\mathrm{Ru}-\mathrm{Ru}$ bond in complex $\mathbf{G}$ and moreover could demonstrate that the terminal hydride ligand in the resulting diruthenium dihydride complex is more easily protonated than the bridging hydride. ${ }^{30}$

Recently, diazadiene olefin complexes $\left[\mathrm{M}\left(\operatorname{trop}_{2} \mathrm{dad}\right)\right]^{n}$ with low-valent iron or ruthenium centers became accessible 


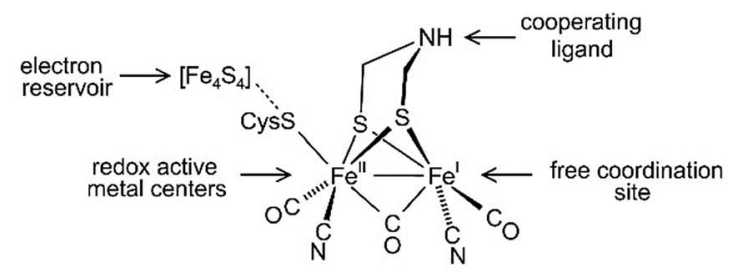

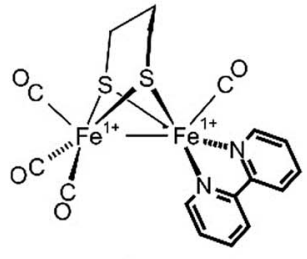

A

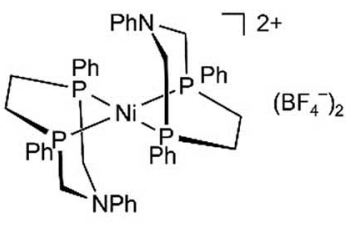

D

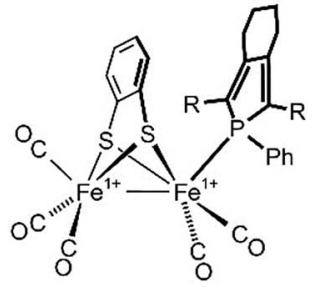

B

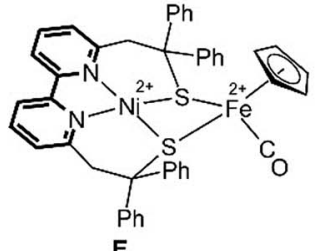

E
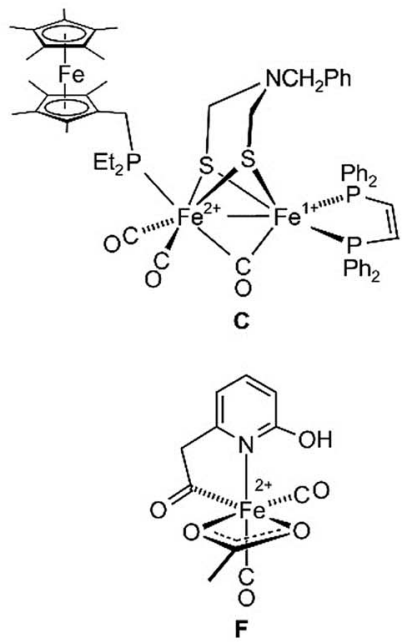

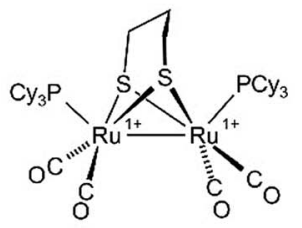

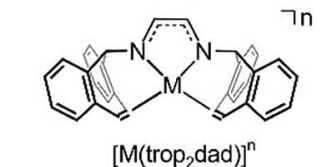

$M=F e(I), n=-1 ; M=R u(0), n=0$

G

Fig. 1 Structure of the [Fe,Fe] hydrogenase active site (top) and some hydrogenase mimics (A-G), as well as the illustration of diazadiene olefin complexes related to this work (bottom).

(Fig. 1). ${ }^{33,34}$ In these complexes, the trop ${ }_{2}$ dad ligand combines the well-established chemical and redox non-innocence of diazadienes (dads) and related ligands ${ }^{35-37}$ with the $\sigma$-donor $/ \pi$ acceptor properties of olefins. ${ }^{30}$ Some of these low-valent metal complexes have remarkable properties. For example, $\left[\mathrm{Ru}^{0}\left(\operatorname{trop}_{2} \mathrm{dad}\right)\right]$ was found to be an efficient catalyst for the clean conversion of aqueous basic methanol or formaldehyde solutions into $\mathrm{H}_{2}$ and carbonate..$^{34,38}$

Herein we report the synthesis of the dinuclear complex $\left[\mathrm{Ru}_{2}\left(\mathrm{Me}_{2} \mathrm{dad}\right)(\mathrm{dbcot})_{2}\right]$ (3) which under 1 bar of $\mathrm{H}_{2}$ is converted to $\left[\mathrm{Ru}_{2} \mathrm{H}(\mu-\mathrm{H})\left(\mathrm{Me}_{2} \mathrm{dad}\right)(\mathrm{dbcot})_{2}\right](3(\boldsymbol{\mu}-\mathbf{H}) \mathbf{H})$ as a fully artificial but functional $[\mathrm{Fe}, \mathrm{Fe}]$ hydrogenase model (Fig. 2). ${ }^{39}$ This complex catalyzes the oxidation of hydrogen to protons and electrons as well as the reversible and selective hydrogenation of vitamin $\mathrm{K}_{3}\left(\mathrm{VK}_{3}\right)$ or vitamin $\mathrm{K}_{2}\left(\mathrm{VK}_{2}\right)$ forming dihydrovitamin $\mathrm{K}_{3}$ $\left(\mathrm{VK}_{3} \mathrm{H}_{2}\right)$ or $\mathrm{VK}_{2}$ hydroquinone $\left(\mathrm{VK}_{2} \mathrm{H}_{2}\right)$ without affecting the $\mathrm{C}=\mathrm{C}$ double bonds of these vitamins.

Refluxing dbcot with ruthenium(III) chloride trihydrate in ethanol and THF quantitatively produces the brown coordination polymer $\left(\left[\mathrm{RuCl}_{2}(\mathrm{dbcot})\right]_{x}\right) \mathbf{1}$, which reacts further with $N, N^{\prime}-$ dimethyldiaminoethane $\left(\mathrm{Me}_{2} \mathrm{en}\right)$ in THF and forms the mononuclear complex $\left[\mathrm{RuCl}_{2}\left(\mathrm{Me}_{2} \mathrm{en}\right)(\mathrm{dbcot})\right] 2$ in $92 \%$ yield (Fig. 2).
The deprotonation of 2 by 2.05 eq. of KO $t$ Bu produced a tetranuclear complex, $[\mathrm{K}]\left[\mathrm{Ru}_{4}(\mu-\mathrm{H})\left(\mathrm{Me}_{2} \mathrm{dad}\right)_{2}(\mathrm{dbcot})_{4}\right]\left([\mathbf{K}]\left[\mathbf{3}_{2}(\mu-\mathbf{H})\right]\right)$, in $40 \%$ yield as the major species (for detailed spectroscopic data of all isolated complexes reported in this work see the ESI $\dagger)^{30}$

Reducing the tetranuclear $[\mathbf{K}]\left[\mathbf{3}_{\mathbf{2}}(\boldsymbol{\mu}-\mathbf{H})\right]$ with 3.4 equivalents of $\mathrm{KC}_{8}$ generates the dianionic dinuclear $[\mathrm{K}]_{2}\left[\mathrm{Ru}_{2}\left(\mathrm{Me}_{2^{-}}\right.\right.$ dad) $\left.(\mathrm{dbcot})_{2}\right]\left([\mathrm{K}]_{2}[3]\right)$ in $85 \%$ yield. The $2: 1$ ratio of dbcot to $\mathrm{Me}_{2} \mathrm{dad}$ and lack of hydride signals in the ${ }^{1} \mathrm{H}$ NMR spectrum suggests the presence of a Ru dimer complex with no hydrides. The low-frequency shift of the $\mathrm{Me}_{2} \mathrm{dad}$ and olefinic protons in $[\mathbf{K}]_{2}[3]$ compared to $[\mathbf{K}]\left[\mathbf{3}_{2}(\boldsymbol{\mu}-\mathbf{H})\right]$ is consistent with a more electron rich complex (see ESI Table $2 \dagger$ ). The oxidation of $[\mathrm{K}]_{2}[3]$ with 2 eq. of $[\mathrm{Fc}]\left[\mathrm{PF}_{6}\right]$ gives a neutral dinuclear complex $\mathrm{Ru}_{2}\left(\mathrm{Me}_{2} \mathrm{dad}\right)(\mathrm{dbcot})_{2}(3)$ in $77 \%$ yield. The ${ }^{1} \mathrm{H}$ NMR spectra of 3 show sharp resonances at $0{ }^{\circ} \mathrm{C}$, indicating the structure shown in Fig. 2, in which one Ru center is coordinated in a $\kappa^{2} \mathrm{~N}, \mathrm{~N}$ fashion, and the other in an $\eta^{4}$ fashion by the bridging $\mathrm{Me}_{2} \mathrm{dad}$ ligand. But broad signals for the aromatic and olefinic protons are observed at room temperature, indicating molecular dynamics phenomena. Various NMR experiments show that two dynamic processes occur: (i) exchange of the $\kappa^{2} \mathrm{~N}, \mathrm{~N} / \eta^{4}$ 

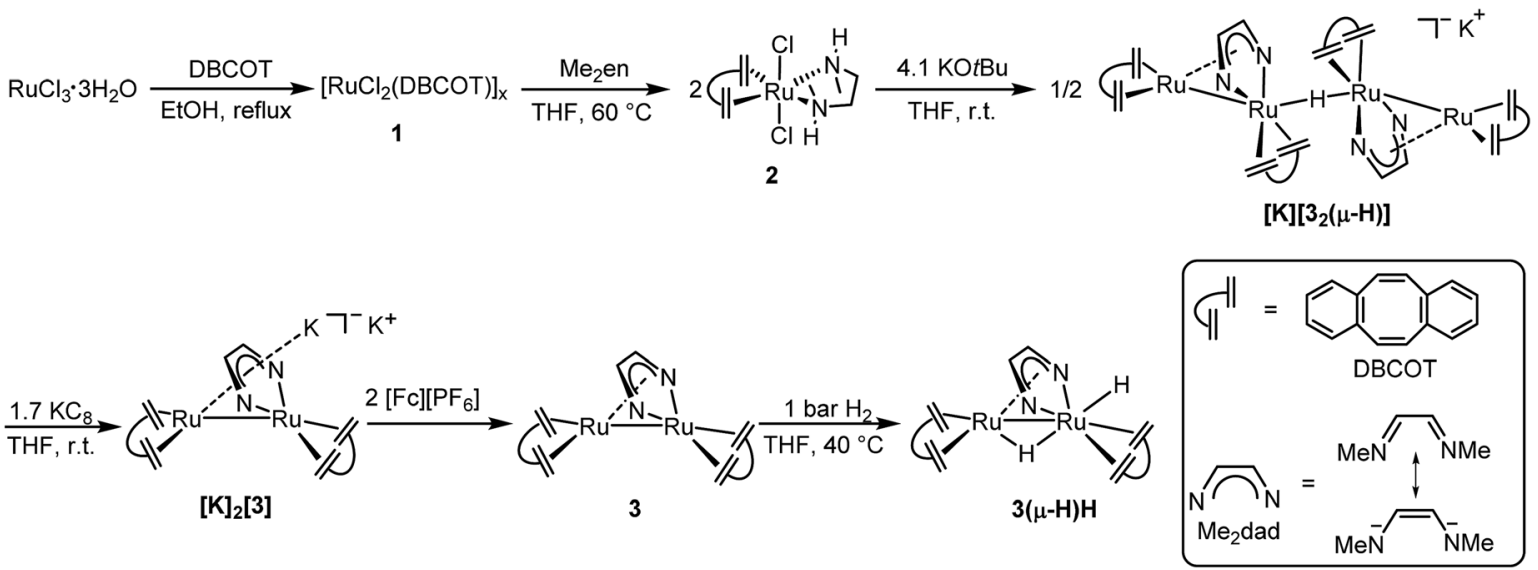

Fig. 2 Preparation of $\left[\mathrm{Ru}_{2} \mathrm{H}(\mu-\mathrm{H})\left(\mathrm{Me}_{2} \mathrm{dad}\right)(\mathrm{dbcot})_{2}\right](3(\mu-\mathrm{H}) \mathrm{H})$. Illustration of the $\mathrm{dbcot}$ and $\mathrm{Me}_{2}$ dad ligand, and six-step synthesis of binuclear complex $3(\mu-\mathrm{H}) \mathrm{H}$.

coordination mode of the $\mathrm{Me}_{2}$ dad ligand between the two $\mathrm{Ru}$ centers and (ii) rotation of the dbcot ligands (see ESI Fig. 3 for details $\dagger$ ). Finally, exposure of 3 to 1 bar of $\mathrm{H}_{2}$ quickly forms a dinuclear dihydride complex, $\mathrm{Ru}_{2} \mathrm{H}(\mu-\mathrm{H})\left(\mathrm{Me}_{2} \mathrm{dad}\right)(\mathrm{dbcot})_{2}$ $(3(\mu-H) H)$, in quantitative yield. The two $\mathrm{Ru}-\mathrm{H}$ resonances at $-0.74 \mathrm{ppm}$ and $-2.74 \mathrm{ppm}$ in THF- $d_{8}$ show a coupling of ${ }^{2} J_{\mathrm{HH}}=$ 8.7 Hz, which suggests that both hydrides coordinate to the same Ru atom..$^{40}$ The NOESY spectrum allows us to propose the structure of $3(\boldsymbol{\mu}-\mathbf{H}) \mathbf{H}$ as shown in Fig. 2 with a bridging hydride $(\delta=-0.74 \mathrm{ppm})$ and a terminal hydride $(\delta=-2.74 \mathrm{ppm})$ (see ESI Fig. $5 \dagger$ ).

Single crystals of $[\mathbf{K}]\left[3_{2}(\mu-\mathbf{H})\right]$ and $[\mathbf{K}]_{2}[3]$ were obtained from a THF/DME/hexane mixture in the presence of 18-crown-6. Crystals of $3(\boldsymbol{\mu}-\mathbf{H}) \mathbf{H}$ were grown by slow evaporation of a saturated benzene solution. All structures were investigated by X-ray diffraction methods and plots are shown in Fig. 3. $[\mathbf{K}]\left[\mathbf{3}_{2}(\mu-\mathbf{H})\right]$ is a tetranuclear complex which contains two bimetallic ruthenium moieties bridged by a hydride. ${ }^{41}$ The complex $[\mathrm{K}]_{2}[3]$ is best described as an ion pair $[\mathbf{K}]^{+}\{\mathbf{K}[3]\}^{-}$in which the $\{\mathbf{K}[3]\}^{-}$ anion consists of a sandwich complex with a (dbcot) $\mathrm{RuN}_{2} \mathrm{C}_{2}$ unit as the central deck to which a Ru(dbcot) fragment binds in an $\eta^{5}$-fashion to one side and a $\mathrm{K}(18$-crown-6) fragment to the other side. The dinuclear dihydride $3(\boldsymbol{\mu}-\mathbf{H}) \mathbf{H}$ contains a bridging and a terminal hydride located on a plane of symmetry including also the two $\mathrm{Ru}$ centers, similar to the complex $\mathrm{Ru}_{2}\left(\mathrm{~S}_{2} \mathrm{C}_{3} \mathrm{H}_{6}\right)(\mu-\mathrm{H})(\mathrm{H})(\mathrm{CO})_{3}\left(\mathrm{PCy}_{3}\right)_{2} \mathbf{G}$ reported by Rauchfuss et $a l .{ }^{30}$ Note that in the $\mathrm{Ru}_{2}$ complex fragments, the $\kappa^{2} \mathrm{~N}, \mathrm{~N} / \eta^{4}$ coordination mode of the diazadiene ligand centers is retained in all complexes. This structural motif is known for related dimeric $\left[\mathrm{Ru}_{2}(\mathrm{CO})_{5}\left(\mathrm{R}_{2} \mathrm{dad}\right)\right]$ complexes. ${ }^{42}$

The $\mathbf{R u}-\mathrm{Ru}$ distances in $[\mathbf{K}]\left[\mathbf{3}_{\mathbf{2}}(\boldsymbol{\mu}-\mathbf{H})\right],[\mathbf{K}]_{2}[3]$ and $\mathbf{3}(\boldsymbol{\mu}-\mathbf{H}) \mathbf{H}$ are $2.6947(5), 2.8239(8)$ and $2.7300(3) \AA$, respectively, similar to the ones observed in the $\mathrm{Ru}(\mathrm{I})$ dimer complexes (2.632-2.937 $\AA),{ }^{24,42,43}$ suggesting the presence of Ru-Ru bonds. The longer $\mathrm{Ru}-\mathrm{Ru}$ distance in $[\mathrm{K}]_{2}[3](2.8239(8) \AA)$ reflects the highly reduced state of this species. Also, the olefinic bonds in $[\mathrm{K}]_{2}[3]$ (average of 1.450(3) $\AA$ ) are longer than the ones in $[\mathbf{K}]\left[3_{2}(\mu-\mathbf{H})\right]$ (average of $1.433(3) \AA$ ) and $3(\boldsymbol{\mu}-\mathbf{H}) \mathbf{H}$ (average of $1.424(3) \AA$ ), indicating strong back donation from the $\mathrm{Ru}-\mathrm{Ru}$ unit into the $\pi^{*}$-orbitals of the coordinated $\mathrm{C}=\mathrm{C}_{\mathrm{dbcot}}$ bonds. This effect increases with increasing anionic charge of the complex (in free dbcot, the average olefin bond length is $1.321 \AA$ ). Note that the $\mathrm{C}=\mathrm{C}_{\mathrm{dbcot}}$ bond lengths coordinated to Ru2 are longer than those bound to Ru1, indicating a higher electron density at Ru2. Of special interest are the $\mathrm{C}-\mathrm{N}$ and $\mathrm{C}-\mathrm{C}$ bond lengths of the diazadiene ligand because they reflect the oxidation state of the ligand and consequently also of the metal. The neutral diimine form, $\mathrm{RN}=\mathrm{CH}-\mathrm{CH}=\mathrm{NR}$, binds to a low-valent metal center, $\mathrm{M}^{n}$, and is characterized by short $\mathrm{C}-\mathrm{N}$ bonds $(\approx 1.29 \AA)$ and a long $\mathrm{C}-\mathrm{C}$ bond $(\approx 1.46 \AA)$. With increasing shift of electron density from the metal center to the ligand, the $\mathrm{C}-\mathrm{N}$ bonds are lengthened while the $\mathrm{C}-\mathrm{C}$ bond shortens: in the diazadiene radical anion $[\mathrm{RN}=\mathrm{CH}-\mathrm{CH}=\mathrm{NR}]^{\cdot-}$ coordinated to $\mathrm{M}^{n+1}, \mathrm{C}-\mathrm{N}$ $\approx 1.33 \AA$ and $\mathrm{C}-\mathrm{C} \approx 1.39 \AA$; in the dianionic bisamido olefin form $[\mathrm{RN}-\mathrm{CH}=\mathrm{CH}-\mathrm{NR}]^{2-}$ coordinated to $\mathrm{M}^{n+2}, \mathrm{C}-\mathrm{N} \approx 1.38 \AA$ and $\mathrm{C}-\mathrm{C} \approx 1.35 \AA^{36,44-46}$ The $\mathrm{C}-\mathrm{N}$ and $\mathrm{C}-\mathrm{C}$ bonds of the $\mathrm{Me}_{2} \mathrm{dad}$ in $[\mathbf{K}]\left[3_{2}(\mu-\mathbf{H})\right],[\mathbf{K}]_{2}[3]$ and $\mathbf{3}(\boldsymbol{\mu}-\mathbf{H}) \mathbf{H}$ are approx. $1.38 \AA$ and 1.39 $\AA$, respectively, indicating a reduced form of the ligand. Consequently, the oxidation states at the Ru centers vary between 0 and +1 . These data illustrate the redox non-innocent behavior of the $\mathrm{Me}_{2}$ dad ligand in these complexes. ${ }^{36,46}$ The bridging coordination modes of $2 \mathrm{e}^{-}$reduced dad and the closely related pyridine-diimine ligands have been reported before. ${ }^{47,48}$

The ability to split $\mathrm{H}_{2}$ into protons and electrons like that of hydrogenases was investigated using the "Rauchfuss test". ${ }^{16}$ In the presence of ten equivalents of $\mathrm{PPh}_{3}$ and $[\mathrm{Fc}]\left[\mathrm{PF}_{6}\right], 3(\mu-\mathbf{H}) \mathbf{H}$ catalytically splits hydrogen into protons and electrons under 1 bar $\mathrm{H}_{2}$ at $40{ }^{\circ} \mathrm{C}$, forming protonated triphenylphosphane $\left[\mathrm{Ph}_{3} \mathrm{PH}\right]\left[\mathrm{PF}_{6}\right]$, and $\mathrm{Cp}_{2} \mathrm{Fe}$ in THF within 1.5 hours (Fig. 4a). More compellingly, $\mathbf{3}(\boldsymbol{\mu}-\mathbf{H}) \mathbf{H}$ is able to catalyze reversibly the hydrogenation of the biologically relevant vitamins $\mathrm{VK}_{3}$ and $\mathrm{VK}_{2}$ (Fig. 4b). ${ }^{49,50}$ Hydrogenation of $\mathrm{VK}_{3}$ was investigated under 1 bar or 15 bar $\mathrm{H}_{2}$ pressure, at $40{ }^{\circ} \mathrm{C}$ or $70{ }^{\circ} \mathrm{C}$ (ESI Table 3, entries 1-3†). With 1 bar $\mathrm{H}_{2}$, a TON of 252 was achieved. Remarkably, $3(\mu-\mathrm{H}) \mathrm{H}$ remained active even after 2 months. At $70{ }^{\circ} \mathrm{C}$ and 15 bar $\mathrm{H}_{2}, 0.13 \mathrm{~mol} \% 3(\mu-\mathrm{H}) \mathrm{H}$ converts $65 \%$ of $\mathrm{VK}_{3}$ to $\mathrm{VK}_{3} \mathrm{H}_{2}$ to give a TON of 220 . Under 15 bar $\mathrm{H}_{2}$, the TOF values at $40^{\circ} \mathrm{C}$ and 

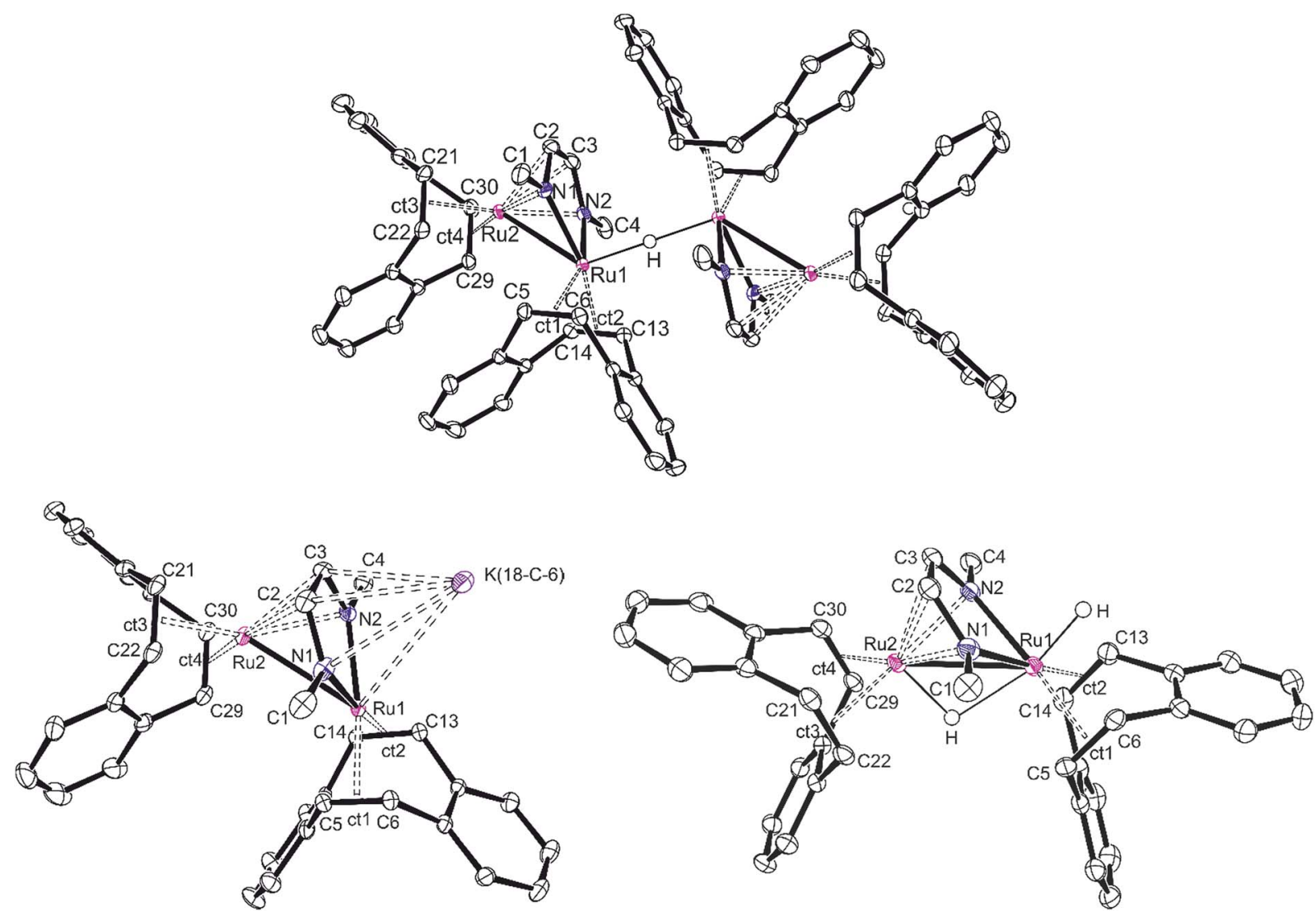

Fig. 3 Structures (ORTEP plots) of $[\mathrm{K}]\left[3_{2}(\mu-\mathrm{H})\right]$ (top), $[\mathrm{K}]_{2}[3]$ (bottom left) and $3(\mu-\mathrm{H}) \mathrm{H}$ (bottom right). [K] represents a $\mathrm{K}^{+}$cation either coordinated to 18 -crown- 6 or THF molecules. Thermal ellipsoids are drawn at the $50 \%$ probability level. Non-relevant hydrogen atoms, solvent molecules, crown ethers, and potassium cations, which are not part of the anionic $\mathrm{Ru}_{2}$ complex, have been removed for clarity. $\mathrm{Ct}_{1-4}$ are the centroids of the coordinated $\mathrm{C} 5=\mathrm{C} 6, \mathrm{C} 13=\mathrm{C} 14, \mathrm{C} 21=\mathrm{C} 22$, and $\mathrm{C} 19=\mathrm{C} 20$ bonds, respectively. Selected bond distances $(\AA)$. [K] $\left.3_{2}(\mu-\mathrm{H})\right]$, Ru1Ru2 2.6947(5), Ru1-Nav 2.107(2), Ru1-ct av 2.014(2), Ru2-Nav 2.173(2), Ru2-ct av 1.991(3), N1-C2 1.381(3), C2-C3 1.382(4), C3-N2 1.379(2), C$C_{\text {olefin av }}$ 1.440(3); [K] [3], Ru1-Ru2 2.8239(8), Ru1-Nav 2.066(2), Ru1-ct av $_{2}$ 1.985(2), Ru2-N2 2.476(2), Ru2-N2 2.293(2), Ru2-ctav 1.970(3), N1-C2 1.399(4), C2-C3 1.406(4), C3-N2 1.390(3), C-Colefin av 1.452(4); 3( $\mu-\mathrm{H}) \mathrm{H}$ (average values from two molecules in one cell), Ru1-Ru2 2.7300(3), Ru1-N $\mathrm{N}_{\mathrm{av}}$ 2.093(2), Ru1-ct $\mathrm{av}_{\mathrm{v}} 2.025, \mathrm{Ru2}-\mathrm{N}_{\mathrm{av}}$ 2.180(2), Ru2-ctav 2.018, N1-C2 1.378(3), C2-C3 1.398(3), C3-N2 1.371(3), C-Colefin av 1.425(3).

$70{ }^{\circ} \mathrm{C}$ are 2.2 and $10 \mathrm{~h}^{-1}$, respectively. $\mathrm{VK}_{2}$ is a more delicate substrate because it tautomerizes. ${ }^{51}$ At room temperature, the hydrogenation of $\mathrm{VK}_{2}$ is more selectively achieved (ESI Table 3, entry $4 \dagger$ ). In addition, the $\mathrm{C}=\mathrm{C}$ double bonds of $\mathrm{VK}_{2}$ remain intact and the hydrogenation occurs selectively at the quinone moiety of the substrate. These catalytic reactions can be reversed. The dehydrogenation of $\mathrm{VK}_{3} \mathrm{H}_{2}$ and $\mathrm{VK}_{2} \mathrm{H}_{2}$ was tested at $40{ }^{\circ} \mathrm{C}$ under $\mathrm{Ar}$ (ESI Table 3, entries 5-7†). The TON values of $\mathrm{VK}_{3} \mathrm{H}_{2}$ and $\mathrm{VK}_{2} \mathrm{H}_{2}$ are 70 (in $48 \mathrm{~h}$ ) and 24 (in $40 \mathrm{~h}$ ), respectively. The TOFs for hydrogenation and dehydrogenation reactions are comparable. A kinetic isotope effect of $k_{\mathrm{H}} / k_{\mathrm{D}}=1.9(2)$ was measured experimentally for the hydrogenation of $\mathrm{VK}_{3}$ by measuring $k_{\mathrm{H}}$ and $k_{\mathrm{D}}$ in separate experiments (ESI, part 7.1†).

Stoichiometric reactions were performed and monitored by NMR spectroscopy in order to gain some insights into possible reaction mechanisms. $\mathbf{3}(\boldsymbol{\mu}-\mathbf{H}) \mathbf{H}$ can be rapidly and quantitatively oxidized at room temperature by ferrocenium salts, $[\mathrm{Fc}][\mathrm{X}]$ ( $\mathrm{X}=\mathrm{PF}_{6}$ or $\left.\mathrm{OTf}\right)$, to give the complex $\left[\mathrm{Ru}_{2}(\mu-\mathrm{H})\left(\mathrm{Me}_{2}-\right.\right.$ dad $\left.)(\mathrm{dbcot})_{2}\right]^{+}\left[\mathrm{PF}_{6}\right]^{-}$or $\left[\mathrm{Ru}_{2}(\mu-\mathrm{H})(\mathrm{OTf})\left(\mathrm{Me}_{2} \mathrm{dad}\right)(\mathrm{dbcot})_{2}\right]$ with a bridging hydride (Fig. $5 \mathrm{a})$ in good yield. The complex $\left[\mathrm{Ru}_{2}(\mu-\right.$ $\left.\mathrm{H})\left(\mathrm{Me}_{2} \mathrm{dad}\right)(\mathrm{dbcot})_{2}\right]\left[\mathrm{PF}_{6}\right][3(\mu-\mathrm{H})]\left[\mathrm{PF}_{6}\right](\mathrm{Ru}-\mathrm{H}, \delta=-10.34 \mathrm{ppm})$ was characterized by NMR in THF- $d_{8}$, while $\left[\mathrm{Ru}_{2}(\mu-\right.$ $\left.\mathrm{H})(\mathrm{OTf})\left(\mathrm{Me}_{2} \mathrm{dad}\right)(\mathrm{dbcot})_{2}\right][3(\boldsymbol{\mu}-\mathbf{H})(\mathrm{OTf})]$ was isolated in crystalline form. Characterization of this complex by single crystal Xray diffraction reveals the presence of a structure closely related to $3(\mu-\mathbf{H}) \mathbf{H}$ with a triflate anion bound to Ru1 instead of the terminal hydride (see Fig. 2 and ESI Fig. $2 \dagger$ ). In THF solution, partial dissociation occurs to give $[3(\mu-\mathrm{H})][\mathrm{OTf}](\mathrm{Ru}-\mathrm{H}, \delta=$ $-10.34 \mathrm{ppm})$ and $[3(\mu-\mathrm{H})(\mathrm{OTf})](\mathrm{Ru}-\mathrm{H}, \delta=-10.18 \mathrm{ppm})$ in a $1: 9$ ratio. These results indicate that the radical cation salt $[3(\mu-\mathbf{H}) \mathbf{H}]^{++}[\mathbf{X}]^{-}$as a primary oxidation product rapidly loses hydrogen to give $[3(\mu-\mathrm{H})][\mathrm{X}]$ (Fig. 6 ). The cyclic voltammogram of $3(\boldsymbol{\mu}-\mathbf{H}) \mathbf{H}$ shows only one irreversible oxidation peak in THF (ESI Fig. $14 \dagger$ ). Our attempts to characterize $[3(\mu-\mathbf{H}) \mathbf{H}]^{++}[\mathrm{X}]^{-}$by EPR spectroscopy failed so far and oxidation of $3(\mu-\mathbf{H}) \mathbf{H}$ with $[\mathrm{Fc}][\mathrm{OTf}]$ or reduction of $[3(\boldsymbol{\mu}-\mathrm{H})(\mathrm{OTf})]$ with $\mathrm{Cp}_{2} \mathrm{Co}$ at $20 \mathrm{~K}$ in MeTHF glass afforded only very weak EPR signals characteristic of (a mixture of) metal-centered radical species with $g$-values in the range of 2.6-1.8 and 2.5-1.7, respectively, which are unlikely to stem from any of the paramagnetic on-cycle catalytic intermediates (such as $[3(\boldsymbol{3}-\mathbf{H}) \mathbf{H}]^{++}$or $[3(\mu-\mathbf{H})]^{;} ;$vide infra). Note that 
complex $[3(\boldsymbol{\mu}-\mathbf{H})(\mathbf{O T f})]$ is catalytically active in both reactions (a) and (b) shown in Fig. 4.

In the next experiment, $3(\boldsymbol{\mu}-\mathbf{H}) \mathbf{H}$ was oxidized with one equivalent of $[\mathrm{Fc}]\left[\mathrm{PF}_{6}\right]$ in the presence of one equivalent of $\mathrm{PPh}_{3}$. Exclusively, $\quad\left[\mathrm{Ru}_{2}(\mu-\mathrm{H})\left(\mathrm{Me}_{2} \mathrm{dad}\right)(\mathrm{dbcot})_{2}\left(\mathrm{PPh}_{3}\right)\right]\left[\mathrm{PF}_{6}\right], \quad[3(\mu-$ $\left.\mathbf{H})\left(\mathbf{P P h}_{3}\right)\right]\left[\mathbf{P F}_{6}\right],{ }^{31} \mathrm{P}$ NMR: $\delta=32.8 \mathrm{ppm}$, was obtained and no phosphonium salt, $\left[\mathrm{Ph}_{3} \mathrm{PH}\right]\left[\mathrm{PF}_{6}\right]$, was formed (Fig. $5 \mathrm{~b}$ and ESI, Fig. $\left.6^{\dagger}\right)$. The compound $\left[3(\mu-\mathbf{H})\left(\mathbf{P P h}_{3}\right)\right]^{+}$was also obtained from the reaction of $[3(\mu-\mathbf{H})(\mathbf{O T f})]$ and $\mathrm{PPh}_{3}$. Furthermore, the $\mathrm{PPh}_{3}$ ligand in $\left[\mathbf{3}(\boldsymbol{\mu}-\mathbf{H})\left(\mathbf{P P h}_{3}\right)\right]^{+}$can be replaced by a stronger ligand such as $\mathrm{P}(\mathrm{OMe})_{3}$ (ESI, Fig. $\left.7 \dagger\right)$. When $\mathbf{3}(\boldsymbol{\mu}-\mathbf{H}) \mathbf{H}$ was exposed to 1 bar of $\mathrm{D}_{2}$, either at room temperature or under catalytic conditions, the complex $\left[\mathrm{Ru}_{2} \mathrm{D}(\mu-\mathrm{H})\left(\mathrm{Me}_{2} \mathrm{dad}\right)(\mathrm{dbcot})_{2}\right]$ was observed (ESI, Fig. 8 and $9 \dagger$ ), along with deuterium incorporation into the substrate, $\mathrm{VK}_{3} \mathrm{D}_{2}$, when present (ESI, Fig. $9 \dagger$ ). In combination, these experiments show that (i) only the terminal hydride in $\mathbf{3}(\boldsymbol{\mu}-\mathbf{H}) \mathbf{H}$ participates in the reactions, and that (ii) the ligand at the terminal site of Ru1 can be exchanged. When experiments were performed under 1 bar of $\mathrm{H}_{2}$ in the absence of an oxidant, no reaction took place and $3(\mu-\mathbf{H}) \mathbf{H}$ remained intact. When $\mathbf{3}(\boldsymbol{\mu}-\mathbf{H}) \mathbf{H}$ was reacted in the presence of a large

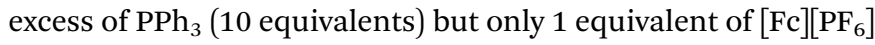
under 1 bar of $\mathrm{H}_{2}$, the cationic $\mathrm{PPh}_{3}$ complex $\left[3(\boldsymbol{\mu}-\mathbf{H})\left(\mathbf{P P h}_{3}\right)\right]^{+}$ was observed but no $\left[\mathrm{Ph}_{3} \mathrm{PH}\right]^{+}$(Fig. $5 \mathrm{~b}$ and ESI, Fig. $10 \dagger$ ). However, the formation of $\left[\mathbf{P P h}_{3} \mathbf{H}\right]^{+}$from a mixture of $[3(\mu-$ $\left.\mathbf{H})\left(\mathbf{P P h}_{3}\right)\right]^{+}, \mathrm{PPh}_{3}$ and $\mathrm{H}_{2}$ was observed in the presence of 1 equiv. of $\mathrm{Fc}^{+}$(Fig. 5c and ESI, Fig. 11†). These experiments suggest that two equivalents of ferrocenium are needed to observe turnover with $3(\boldsymbol{\mu}-\mathbf{H}) \mathbf{H}$ as the catalyst, and that the second equivalent is needed to rapidly convert $3(\mu-\mathbf{H}) \mathbf{H}$ into $[3(\mu-\mathbf{H})]^{+}$in order to prevent the reaction between the $\left[\mathrm{Ph}_{3} \mathrm{PH}\right]^{+}$ and the hydridic complex $3(\mu-\mathrm{H}) \mathrm{H}$, according to $\left[\mathrm{Ph}_{3} \mathrm{PH}^{+}\right]+3(\mu-$ $\mathbf{H}) \mathbf{H} \rightarrow\left[3(\mu-\mathbf{H})\left(\mathbf{P P h}_{3}\right)\right]^{+}+\mathrm{H}_{2}$, which was experimentally found to be exergonic (see ESI Fig. 12†).

Taken together, these results support the proposed catalytic cycle A shown in Fig. 6. 3( $\mu-\mathrm{H}) \mathrm{H}$ is first oxidized with loss of one electron to give the radical cation $[3(\mu-\mathbf{H}) \mathbf{H}]^{++}$, which rapidly loses half an equivalent of $\mathrm{H}_{2}$ to yield $[3(\mu-\mathrm{H})]^{+}$. This complex with a labile coordination site at Ru1 is intercepted by $\mathrm{PPh}_{3}$ to

$$
\begin{aligned}
& \text { a } \\
& 2 \mathrm{PPh}_{3}+2\left[\mathrm{Cp}_{2} \mathrm{Fe}\right]\left[\mathrm{PF}_{6}\right] \stackrel{3(\mu-\mathrm{H}) \mathrm{H}, 1 \text { bar } \mathrm{H}_{2}}{\longrightarrow} 2\left[\mathrm{PPh}_{3} \mathrm{H}\right]\left[\mathrm{PF}_{6}\right]+2 \mathrm{Cp}_{2} \mathrm{Fe}
\end{aligned}
$$

b

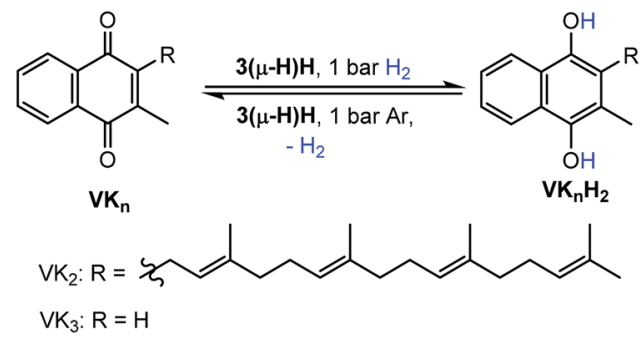

Fig. 4 Reactivity of complex $3(\mu-\mathrm{H}) \mathrm{H}$. (a) Catalytic splitting of $\mathrm{H}_{2}$ by $3(\mu-\mathrm{H}) \mathrm{H}$ using $\mathrm{PPh}_{3}$ and $\left[\mathrm{Fc}_{\mathrm{C}}\right]\left[\mathrm{PF}_{6}\right]$ as the proton and electron acceptors, respectively. (b) Hydrogenation of $\mathrm{VK}_{3}$ and $\mathrm{VK}_{2}$ to dihydrovitamin $\mathrm{K}_{3}$ $\left(\mathrm{VK}_{3} \mathrm{H}_{2}\right)$ and $V \mathrm{~K}_{2}$ hydroquinone $\left(\mathrm{VK}_{2} \mathrm{H}_{2}\right)$ and the reverse dehydrogenations both promoted by $3(\mu-\mathrm{H}) \mathrm{H}$ as the catalyst.

a

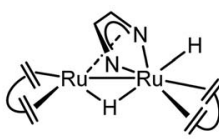

$3(\mu-\mathrm{H}) \mathrm{H}$

b

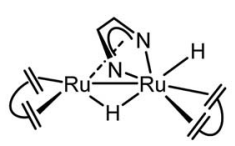

$3(\mu-\mathrm{H}) \mathrm{H}$
$\left[3(\mu-\mathrm{H})\left(\mathrm{PPh}_{3}\right)\right]\left[\mathrm{PF}_{6}\right]$

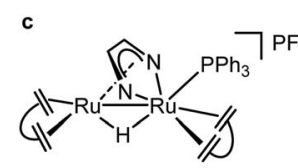

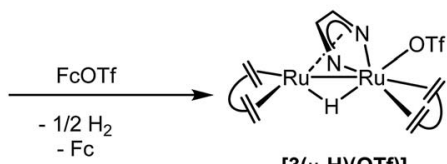

$[3(\mu-\mathrm{H})(\mathrm{OTf})]$
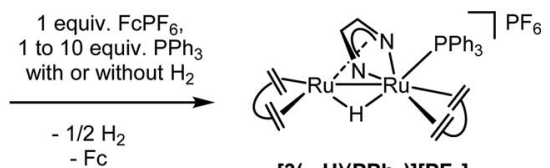

$\left[3(\mu-H)\left(\mathrm{PPh}_{3}\right)\right]\left[\mathrm{PF}_{6}\right]$

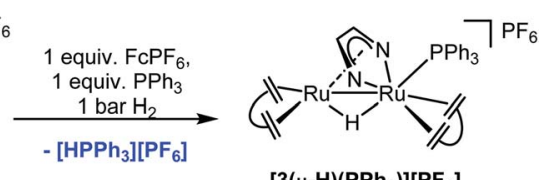

$\left[3(\mu-\mathrm{H})\left(\mathrm{PPh}_{3}\right)\right]\left[\mathrm{PF}_{6}\right]$
Fig. 5 Stoichiometric reactions performed to support the proposed mechanisms.

give $\left[3(\boldsymbol{\mu}-\mathbf{H})\left(\mathbf{P P h}_{3}\right)\right]^{+}$which is the resting state within the catalytic cycle. The complex $\left[3(\boldsymbol{3}-\mathbf{H})\left(\mathbf{P P h}_{3}\right)\right]^{+}$is in equilibrium with $[3(\mu-H)]^{+}$(likely as a solvated adduct $[3(\mu-\mathbf{H})(\text { solv })]^{+}$and present at low concentration), which may coordinate with $\mathrm{H}_{2}$ to give $\left[3(\mu-\mathbf{H})\left(\mathbf{H}_{2}\right)\right]^{+}$. Deprotonation of $\left[3(\mu-\mathbf{H})\left(\mathbf{H}_{2}\right)\right]^{+}$by $\mathrm{PPh}_{3}$ (vide infra) gives the phosphonium salt $\left[\mathrm{Ph}_{3} \mathrm{PH}\right]^{+}$and regenerates $3(\mu-$ H)H. A second equivalent of oxidant is needed to turn over the catalytic cycle to give back $\left[3(\boldsymbol{\mu}-\mathbf{H})\left(\mathbf{P P h}_{3}\right)\right]^{+}$as the resting state via the reaction sequence given above.

A slightly different reaction path was observed for the reaction of $3(\mu-\mathbf{H}) \mathbf{H}$ with quinones. The reaction between $3(\mu-\mathbf{H}) \mathbf{H}$ and $\mathrm{VK}_{3}$, in the absence of $\mathrm{H}_{2}$, formed a thick suspension, which prevents further characterization by NMR spectroscopy. However, upon addition of a large excess of NaOTf, a signal attributed to complex $[3(\mu-\mathrm{H})(\mathbf{O T f})]$ was detected by ${ }^{1} \mathrm{H}$ NMR spectroscopy. No reaction between NaOTf and $\mathbf{3}(\boldsymbol{\mu}-\mathbf{H}) \mathbf{H}$ was observed in the absence of $\mathrm{VK}_{3}$. These data suggest that the terminal hydride of $3(\mu-\mathrm{H}) \mathrm{H}$ was transferred to $\mathrm{VK}_{3}$, which then formed a protonated semiquinone oxygen bound species $[3(\mu-$ $\mathbf{H})\left(\mathbf{V K}_{3} \mathbf{H}\right)$ ] (see the proposed structure based on DFT calculations in Fig. 8), and that $\mathrm{VK}_{3} \mathrm{H}^{-}$is labile enough to be partially displaced by OTf ${ }^{-}$. When followed by EPR spectroscopy at room temperature, the reaction between $\mathbf{3}(\boldsymbol{\mu}-\mathbf{H}) \mathbf{H}$ and $\mathrm{VK}_{3}$ led to the formation of one organic radical species, which is detected by EPR spectroscopy at room temperature when $3(\mu-\mathbf{H}) \mathbf{H}$ is reacted with $\mathrm{VK}_{3}$. The signal disappears with time resulting in the formation of the EPR silent and sparsely soluble $\left[3(\mu-\mathbf{H})\left(\mathbf{V K}_{3} \mathbf{H}\right)\right]$ as the only product. With the symmetrical benzoquinone 2,5-ditert-butyl-p-benzoquinone as the model substrate, in situ monitoring of the reaction with $\mathbf{3}(\boldsymbol{\mu}-\mathbf{H}) \mathbf{H}$ afforded immediately the paramagnetic HSQ (protonated semi-quinone) species (doublet, $g_{\text {iso }}=2.005, A_{\text {iso }}^{\mathrm{H}}=10.0 \mathrm{~Hz}$; see ESI part 7.4†).

These observations support the catalytic cycle B shown in red in Fig. 6, in which the neutral semiquinone radical $\mathbf{V K H}^{\circ}$ and the neutral organometallic $\mathrm{Ru}_{2} \operatorname{radical}[3(\mu-\mathrm{H})]^{\cdot}$ were formed. It 


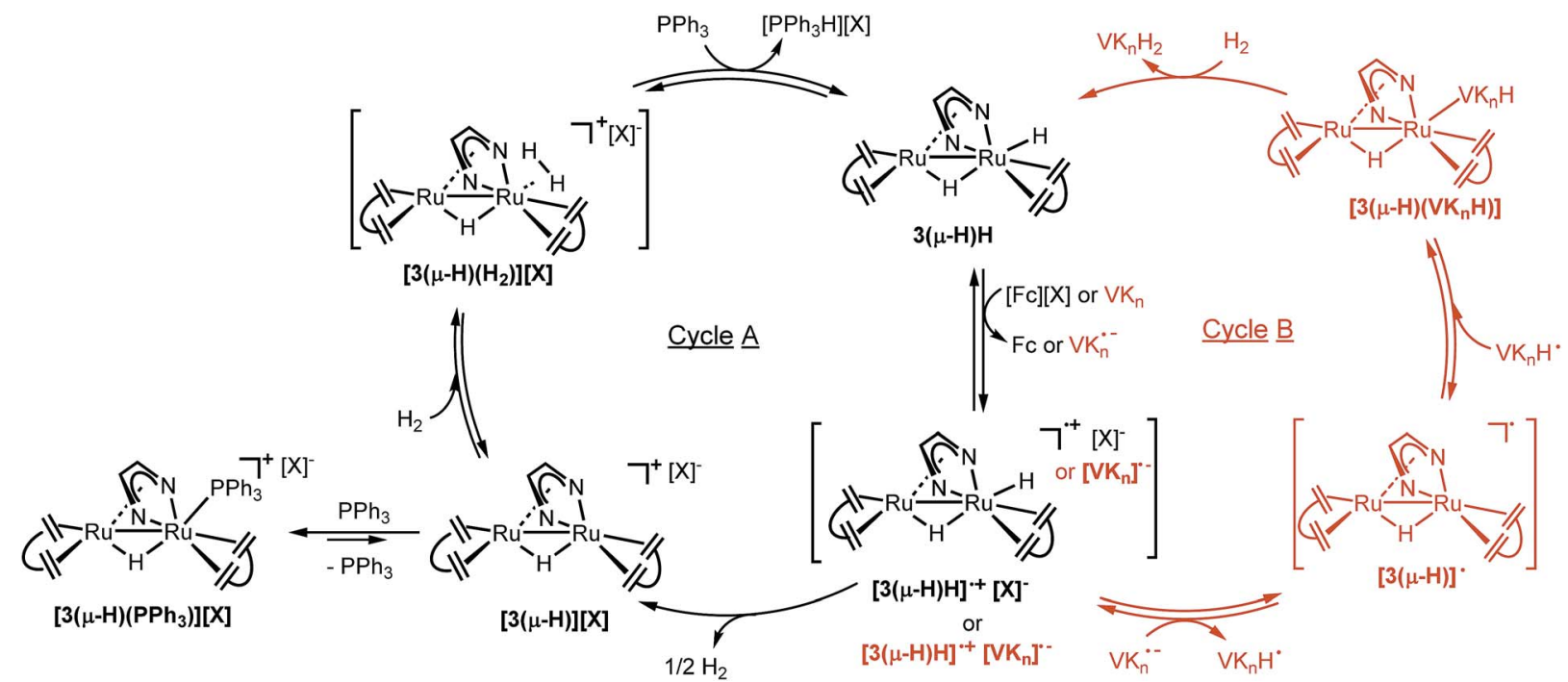

Fig. 6 Proposed mechanisms of $\mathrm{H}_{2}$ splitting by $3(\mu-\mathrm{H}) \mathrm{H}$ using $\mathrm{PPh}_{3}$ and $[\mathrm{Fc}]\left[\mathrm{PF}_{6}\right]$ as the proton and electron acceptors $(\mathrm{Cycle} A$, left), and hydrogenation of vitamin $\mathrm{K}_{n}(n=2$ or 3 ) to their hydroquinone analogs by $3(\mu-\mathrm{H}) \mathrm{H}$ (Cycle $\mathrm{B}$, right).

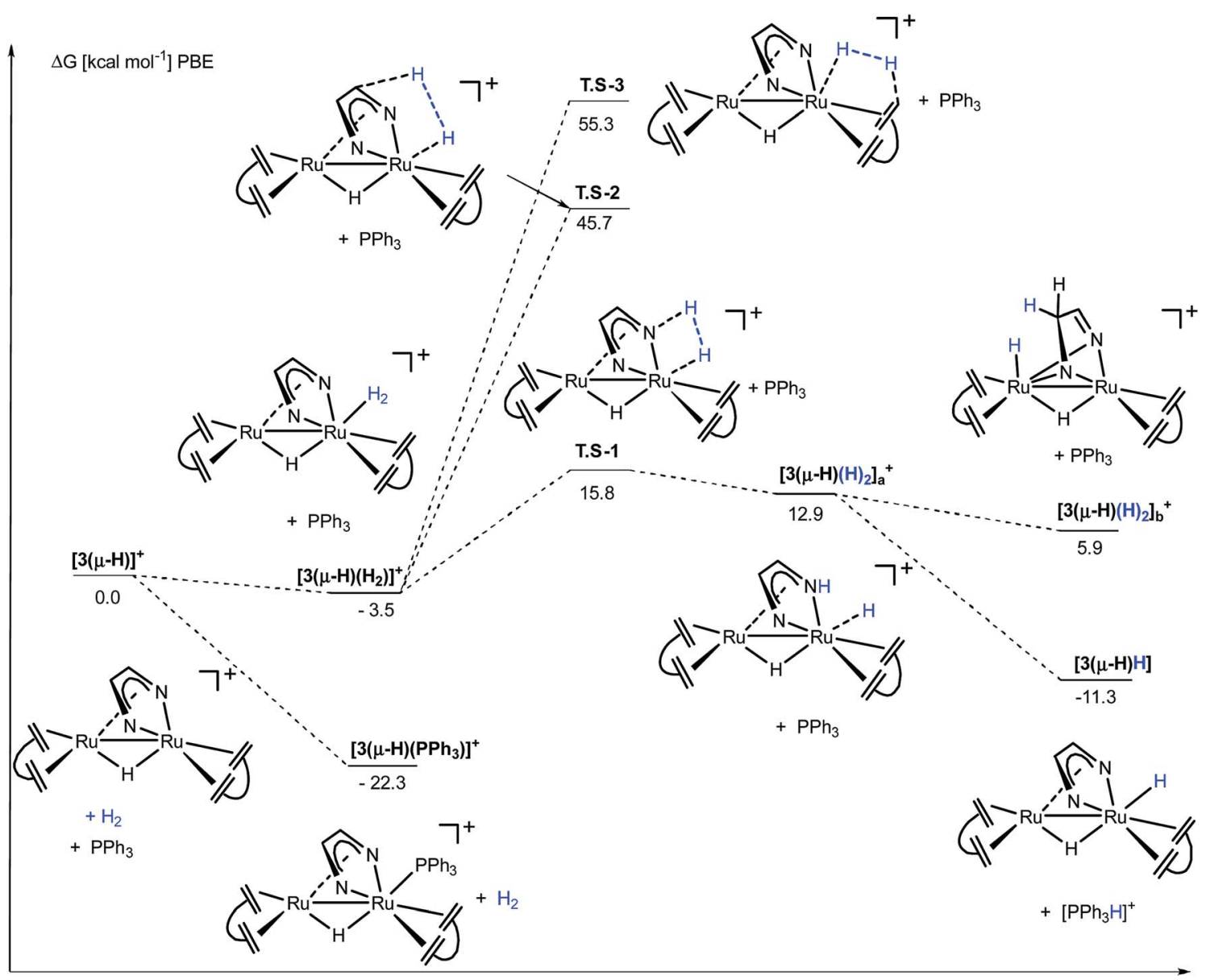

Reaction coordinates

Fig. 7 DFT calculation for the activation of $\mathrm{H}_{2}$ from $[3(\mu-\mathrm{H})]^{+}$in the presence of $\mathrm{PPh}_{3}$. The transition state for the deprotonation of the $\mathrm{H}_{2}$ complex by $\mathrm{PPh}_{3}$ was not found; however, the direct reaction path from $\left[3(\mu-\mathrm{H})\left(\mathrm{H}_{2}\right)\right]^{+}\left(-3.5 \mathrm{kcal} \mathrm{mol}^{-1}\right)$ to $3(\mu-\mathrm{H}) \mathrm{H}+\left[\mathrm{Ph}{ }_{3} \mathrm{PH}\right]^{+}\left(-11.3 \mathrm{kcal} \mathrm{mol}{ }^{-1}\right)$ cannot be excluded. 


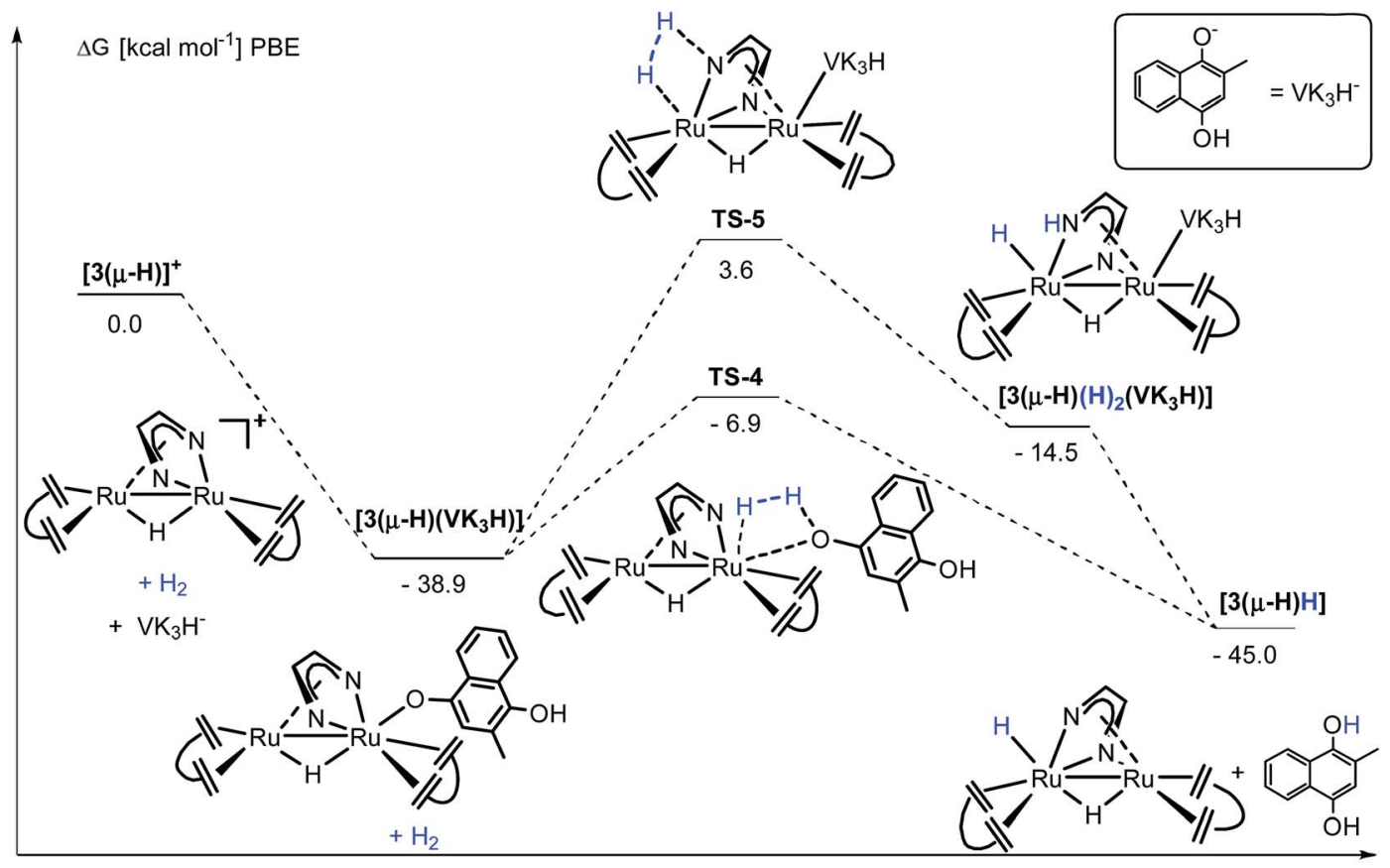

Reaction coordinates

Fig. 8 DFT calculation for the activation of $\mathrm{H}_{2}$ from $[3(\mu-\mathrm{H})]^{+}$in the presence of $\mathrm{VK}_{3} \mathrm{H}^{-}$.

is still unclear if these radical species are formed via direct hydrogen transfer from $3(\boldsymbol{\mu}-\mathbf{H}) \mathbf{H}$ to $\mathrm{VK}_{n}$, or via initial electron transfer to form the oxidized complex $[3(\boldsymbol{\mu}-\mathbf{H}) \mathbf{H}]^{++}$and the reduced quinone $\left[\mathbf{V K}_{n}\right]^{]^{--}}$, followed by proton transfer to form $[3(\mu-\mathbf{H})]^{\cdot}$ and $\left[\mathbf{V K}_{n} \mathbf{H}\right]^{*}$. Subsequent radical recombination with net reduction of the semiquinone radical forms the observed complex $\left[3(\mu-\mathbf{H})\left(\mathbf{V K}_{n} \mathbf{H}\right)\right]$. This complex is subsequently hydrogenated by $\mathrm{H}_{2}$ to give the product $\mathbf{V K}_{\boldsymbol{n}} \mathbf{H}_{2}$ and $\mathbf{3}(\boldsymbol{\mu}-\mathbf{H}) \mathbf{H}$, which is the resting state in this cycle as observed during a single turnover experiment (ESI, Fig. 13†). In this mechanism, the observation of $\mathbf{3}(\boldsymbol{\mu}-\mathbf{H}) \mathbf{H}$ as the only species present after a single turnover experiment is consistent with a less acidic product $\mathrm{VK}_{n} \mathrm{H}_{2}$ compared to $\left[\mathrm{Ph}_{3} \mathrm{PH}\right]^{+}$.

The activation steps of $\mathrm{H}_{2}$ by the $\mathrm{Ru}_{2}\left(\mathrm{Me}_{2} \mathrm{dad}\right)$ core, in both catalytic reactions, were investigated by DFT calculations without using structural simplification $(\Delta G$ values are given here, see Fig. 7 and ESI part $8 \dagger$ ). In the absence of other substrates, $\mathrm{H}_{2}$ adds to $[3(\boldsymbol{\mu}-\mathbf{H})]^{+}$to give $\left[3(\boldsymbol{\mu}-\mathbf{H})\left(\mathbf{H}_{2}\right)\right]^{+}$in a weakly exergonic reaction. This complex can react with a basic substrate like $\mathrm{PPh}_{3}$ to give the products $3(\mu-\mathbf{H}) \mathbf{H}$ and $\left[\mathrm{Ph}_{3} \mathrm{PH}\right]^{+}$ in an overall exergonic reaction $\left(-11.3 \mathrm{kcal} \mathrm{mol}^{-1}\right)$ although we did not succeed in finding any transition states for this bimolecular reaction. Alternatively, heterolytic cleavage across one $\mathrm{Ru}-\mathrm{N}$ bond is energetically accessible via TS-1 at $15.8 \mathrm{kcal} \mathrm{mol}^{-1}$ to give $\left[3(\mu-\mathbf{H})(\mathbf{H})_{2}\right]_{\mathrm{a}}{ }^{+}$. This complex can either rearrange into complex $\left[3(\mu-H)(H)_{2}\right]_{\mathbf{b}}{ }^{+}$to give a hydrogenated $\mathrm{C}=\mathrm{N}$ bond of the $\mathrm{Me}_{2}$ dad ligand or the acidic $\mathrm{NH}$ group is deprotonated to give the products $3(\boldsymbol{\mu}-\mathbf{H}) \mathbf{H}$ and $\left[\mathrm{Ph}_{3} \mathrm{PH}\right]^{+}$. Note that the direct heterolytic cleavage of $\mathrm{H}_{2}$ across a Ru C vector via TS-2 and the hydrogenation of one of the $\mathrm{C}=\mathrm{C}_{\mathrm{dbcot}}$ bonds via TS-3 are both highly unfavorable processes. With $[3(\mu-\mathrm{H})]^{+}, \mathrm{PPh}_{3}$ forms a stable complex, $\left[\mathbf{3}(\boldsymbol{\mu}-\mathbf{H})\left(\mathbf{P P h}_{3}\right)\right]^{+}\left(-22.3 \mathrm{kcal} \mathrm{mol}^{-1}\right)$, which agrees with our assumption that this is the resting state in the catalytic splitting of $\mathrm{H}_{2}$ with $\mathrm{PPh}_{3}$ and [Fc][X]. The DFT calculations, for the reaction with $\mathrm{VK}_{3}$ (Fig. 8), confirm that $\mathrm{VK}_{3} \mathrm{H}^{-}$ forms a stable complex, $\left[3(\boldsymbol{\mu}-\mathbf{H})\left(\mathbf{V K}_{3} \mathbf{H}\right)\right]\left(-38.9 \mathrm{kcal} \mathrm{mol}^{-1}\right)$, in the reaction with $[3(\mu-\mathbf{H})]^{+}$. But in this case, the final products $\mathrm{VK}_{3} \mathrm{H}_{2}$ and $3(\mu-\mathbf{H}) \mathbf{H}\left(-45.0 \mathrm{kcal} \mathrm{mol}^{-1}\right)$ are more stable. That is, the adduct $\left[\mathbf{3}(\boldsymbol{\mu}-\mathbf{H})\left(\mathbf{V K}_{3} \mathbf{H}\right)\right]$ is not the resting state in this cycle but $3(\mu-\mathbf{H}) \mathbf{H}$. The cleavage of $\mathrm{H}_{2}$ involves a classical sigma-bond metathesis transition state TS-4 at $32 \mathrm{kcal} \mathrm{mol}^{-1}$ in which hydrogen is activated across the oxygen atom of the coordinated $\mathrm{VK}_{3} \mathrm{H}$ and the ruthenium metal center. Subsequently, TS-4 collapses in a strongly exergonic reaction to give the products $\mathbf{V K}_{3} \mathbf{H}_{2}$ and $\mathbf{3}(\mu-\mathbf{H}) \mathbf{H}$. This finding agrees with the measured kinetic isotope effect (1.89), which indicates that the cleavage of $\mathrm{H}_{2}$ is likely involved in the rate determining step. The activation of $\mathrm{H}_{2}$ may also occur across a $\mathrm{Ru}-\mathrm{N}$ bond and involves the second $\mathrm{Ru}$ center situated far from the $\mathrm{Ru}-\mathrm{VK}_{3} \mathrm{H}$ unit but this activation barrier is significantly higher $\left(E^{\mathrm{a}}=42.5 \mathrm{kcal} \mathrm{mol}^{-1}\right)$.

\section{Conclusions}

The complex $\left[\mathrm{Ru}_{2} \mathrm{H}(\mu-\mathrm{H})\left(\mathrm{Me}_{2} \mathrm{dad}\right)(\mathrm{dbcot})_{2}\right], \mathbf{3}(\boldsymbol{\mu}-\mathbf{H}) \mathbf{H}$, can be regarded as a fully artificial mimic of binuclear $[\mathrm{Fe}, \mathrm{Fe}]$ hydrogenases. The $\mathrm{Ru}_{2}\left(\mathrm{Me}_{2} \mathrm{dad}\right)$ core serves as an electron reservoir and $[\mathrm{K}]_{2}\left[\mathrm{Ru}_{2}\left(\mathrm{Me}_{2} \mathrm{dad}\right)(\mathrm{dbcot})_{2}\right],[\mathrm{K}]_{2}[3]$, is the most reduced species and $\left[\mathrm{Ru}_{2}\left(\mathrm{Me}_{2} \mathrm{dad}\right)(\mathrm{dbcot})_{2}\right], 3$, is the most oxidized species. The $\mathrm{Me}_{2}$ dad ligand binds in an $\mathrm{N}, \mathrm{N}-\kappa^{2}$-fashion to one $\mathrm{Ru}$ center, resulting in a five-membered $\mathrm{RuN}_{2} \mathrm{C}_{2}$ heterocycle with a conjugated $\pi$-electron system. Formally, this $\mathrm{RuN}_{2} \mathrm{C}_{2}$ heterocycle coordinates to a second $\mathrm{Ru}$ center as a heteroatom 
analogue of archetypical cyclopentadienyl ligands, a structural feature known for dinuclear $\mathrm{Ru}_{2}$ (dad) complexes. However, the $\mathrm{Ru}_{2}$ (dad) complexes reported in the literature carry $\mathrm{CO}$ as additional ligands and are likely too unstable to serve as efficient catalysts. In this study, the very rigid and concave shaped dibenzocyclooctatriene, dbcot, was used as a neutral four electron $\pi$-donor and $\pi^{*}$-acceptor ligand, which stabilizes all complexes. A Ru-Ru interaction of about $2.7 \AA$ is observed in all complexes, structurally characterized by single crystal X-ray diffraction methods, which is remarkably invariant. Furthermore, the $\mathrm{C}=\mathrm{C}_{\mathrm{dbcot}}$ units bound to the Ru centers do not differ much in length (by $0.05 \AA$ between $[\mathbf{K}]_{2}[3]$ (longest) and $[3(\boldsymbol{\mu}-\mathbf{H})]$ $\left[\mathbf{P F}_{6}\right]$ (shortest)), indicating that the electron densities at the $\mathrm{Ru}$ centers in the various complexes are rather similar. Small structural and electronic variances at the metal centers are also a feature of $[\mathrm{Fe}, \mathrm{Fe}]$ and $[\mathrm{Ni}, \mathrm{Fe}]$ hydrogenases. ${ }^{3,24,52-58}$ The complex $3(\boldsymbol{\mu}-\mathbf{H}) \mathbf{H}$ is a catalyst that splits $\mathrm{H}_{2}$ into protons and electrons in the presence of $\mathrm{PPh}_{3}$ and $[\mathrm{Fc}]\left[\mathrm{PF}_{6}\right]$, forming $\left[\mathrm{Ph}_{3} \mathrm{PH}\right]$ $\left[\mathrm{PF}_{6}\right]$ and $\mathrm{Cp}_{2} \mathrm{Fe}$ (Rauchfuss test for hydrogenase activity), and reversibly and selectively hydrogenates vitamins $\mathrm{VK}_{3}$ or $\mathrm{VK}_{2}$, which are natural substrates for the enzyme hydrogen:quinone oxidoreductase. Spectroscopic data strongly suggest that like in hydrogenases, multiple coupled electron and proton transfer steps might be involved in these reactions. Clearly, the observed activities and efficiencies must be significantly improved. But this investigation demonstrates that redox and chemically noninnocent ligands may be key components and their variation may allow further improvements and uncovering of new bearings in synthesizing small molecular hydrogenase mimics.

\section{Conflicts of interest}

There are no conflicts to declare.

\section{Acknowledgements}

We thank Dr Reinhard O. Kissner and Jean-Pierre H. Oudsen for their kind help with EPR measurements. This work was supported by the Swiss National Science Foundation and the ETH Zürich. X. Y. is grateful for financial support from the China Scholarship Council. T. L. G. was supported by the ETH Zürich Postdoctoral Fellowship Program, co-funded by the ETH ZurichMarie Curie action for people (FEL-14 15-1).

\section{Notes and references}

1 M. Senger, K. Laun, F. Wittkamp, J. Duan, M. Haumann, T. Happe, M. Winkler, U.-P. Apfel and S. T. Stripp, Angew. Chem., Int. Ed., 2017, 56, 16503-16506.

2 M. Winkler, M. Senger, J. Duan, J. Esselborn, F. Wittkamp, E. Hofmann, U.-P. Apfel, S. T. Stripp and T. Happe, Nat. Commun., 2017, 8, 16115.

3 W. Lubitz, H. Ogata, O. Rudiger and E. Reijerse, Chem. Rev., 2014, 114, 4081-4148.

4 C. Tard and C. J. Pickett, Chem. Rev., 2009, 109, 2245-2274.
5 R. Cammack, M. Frey and R. Robson, Hydrogen as a fuel: Learning from nature, CRC Press, London and New York, 2002.

6 A. Volbeda, M.-H. Charon, C. Piras, E. C. Hatchikian, M. Frey and J. C. Fontecilla-Camps, Nature, 1995, 373, 580-587.

7 J. W. Peters, W. N. Lanzilotta, B. J. Lemon and L. C. Seefeldt, Science, 1998, 282, 1853-1858.

8 S. Shima, O. Pilak, S. Vogt, M. Schick, M. S. Stagni, W. MeyerKlaucke, E. Warkentin, R. K. Thauer and U. Ermler, Science, 2008, 321, 572-575.

9 J. C. Fontecilla-Camps, A. Volbeda, C. Cavazza and Y. Nicolet, Chem. Rev., 2007, 107, 4273-4303.

10 O. R. Luca and R. H. Crabtree, Chem. Soc. Rev., 2013, 42, 1440-1459.

11 M. Trincado and H. Grützmacher, Cooperative Catalysis: Designing Efficient Catalysts for Synthesis, Wiley-VCH Verlag GmbH \& Co., Weinheim, 2015, ch. 3, pp. 67-105.

12 S. Roy, T. L. Groy and A. K. Jones, Dalton Trans., 2013, 42, 3843-3853.

13 R. Becker, S. Amirjalayer, P. Li, S. Woutersen and J. N. H. Reek, Sci. Adv., 2016, 2, e1501014.

14 R. Lill, Nature, 2009, 460, 831-838.

15 S. C. Lee, W. Lo and R. H. Holm, Chem. Rev., 2014, 114, 35793600.

16 J. M. Camara and T. B. Rauchfuss, Nat. Chem., 2012, 4, 2630.

17 C. J. Curtis, A. Miedaner, R. Ciancanelli, W. W. Ellis, B. C. Noll, M. Rakowski DuBois and D. L. DuBois, Inorg. Chem., 2003, 42, 216-227.

18 A. Le Goff, V. Artero, B. Jousselme, P. D. Tran, N. Guillet, R. Métayé, A. Fihri, S. Palacin and M. Fontecave, Science, 2009, 326, 1384-1387.

19 T. B. Liu, D. L. DuBois and R. M. Bullock, Nat. Chem., 2013, 5, 228-233.

20 M. L. Helm, M. P. Stewart, R. M. Bullock, M. R. DuBois and D. L. DuBois, Science, 2011, 333, 863-866.

21 S. E. Smith, J. Y. Yang, D. L. DuBois and R. M. Bullock, Angew. Chem., Int. Ed., 2012, 51, 3152-3155.

22 A. Dutta, D. L. DuBois, J. A. S. Roberts and W. J. Shaw, Proc. Natl. Acad. Sci. U. S. A., 2014, 111, 16286-16291.

23 N. Priyadarshani, A. Dutta, B. Ginovska, G. W. Buchko, M. O'Hagan, S. Raugei and W. J. Shaw, ACS Catal., 2016, 6, 6037-6049.

24 D. Brazzolotto, M. Gennari, N. Queyriaux, T. R. Simmons, J. Pecaut, S. Demeshko, F. Meyer, M. Orio, V. Artero and C. Duboc, Nat. Chem., 2016, 8, 1054-1060.

25 S. Shima, D. F. Chen, T. Xu, M. D. Wodrich, T. Fujishiro, K. M. Schultz, J. Kahnt, K. Ataka and X. L. Hu, Nat. Chem., 2015, 7, 995-1002.

26 T. Liu, M. R. DuBois, D. L. DuBois and R. M. Bullock, Energy Environ. Sci., 2014, 7, 3630-3639.

27 G. Gezer, S. Verbeek, M. A. Siegler and E. Bouwman, Dalton Trans., 2017, 46, 13590-13596.

28 T. Matsumoto, Y. Nakaya, N. Itakura and K. Tatsumi, J. Am. Chem. Soc., 2008, 130, 2458-2459.

29 G. M. Chambers, R. Angamuthu, D. L. Gray and T. B. Rauchfuss, Organometallics, 2013, 32, 6324-6329. 
30 A. K. Justice, R. C. Linck, T. B. Rauchfuss and S. R. Wilson, J. Am. Chem. Soc., 2004, 126, 13214-13215.

31 C. Sommer, C. P. Richers, W. Lubitz, T. B. Rauchfuss and E. J. Reijerse, Angew. Chem., Int. Ed., 2018, 57, 5429-5432.

32 M. Yuki, K. Sakata, Y. Hirao, N. Nonoyama, K. Nakajima and Y. Nishibayashi, J. Am. Chem. Soc., 2015, 137, 4173-4182.

33 C. Lichtenberg, L. Viciu, M. Vogt, R. E. Rodriguez-Lugo, M. Adelhardt, J. Sutter, M. M. Khusniyarov, K. Meyer, B. de Bruin, E. Bill and H. Grutzmacher, Chem. Commun., 2015, 51, 13890-13893.

34 R. E. Rodríguez-Lugo, M. Trincado, M. Vogt, F. Tewes, G. Santiso-Quinones and H. Grützmacher, Nat. Chem., 2013, 5, 342-347.

35 F. Richard Keene, Coord. Chem. Rev., 1999, 187, 121-149.

36 K. G. Caulton, Eur. J. Inorg. Chem., 2012, 435-443.

37 D. L. J. Broere, R. Plessius and J. I. van der Vlugt, Chem. Soc. Rev., 2015, 44, 6886-6915.

38 M. Trincado, V. Sinha, R. E. Rodriguez-Lugo, B. Pribanic, B. de Bruin and H. Grützmacher, Nat. Commun., 2017, 8, 14990.

39 F. Wittkamp, M. Senger, S. T. Stripp and U. P. Apfel, Chem. Commun., 2018, 54, 5934-5942.

40 D. Schott, C. J. Sleigh, J. P. Lowe, S. B. Duckett, R. J. Mawby and M. G. Partridge, Inorg. Chem., 2002, 41, 2960-2970.

41 D. A. Vicic, T. J. Anderson, J. A. Cowan and A. J. Schultz, J. Am. Chem. Soc., 2004, 126, 8132-8133.

42 K. Vrieze, J. Organomet. Chem., 1986, 300, 307-326.

43 E. A. Seddon and K. R. Seddon, The chemistry of ruthenium, Elsevier, 1984.

44 A. Mederos, S. Domínguez, R. Hernández-Molina, J. n. Sanchiz and F. Brito, Coord. Chem. Rev., 1999, 193195, 913-939.
45 C. Mealli, A. Ienco, A. D. Phillips and A. Galindo, Eur. J. Inorg. Chem., 2007, 2007, 2556-2568.

46 K. P. Butin, E. K. Beloglazkina and N. V. Zyk, Russ. Chem. Rev., 2005, 74, 531-553.

47 C. Tejel, M. A. Ciriano, M. P. del Río, F. J. van den Bruele, D. G. H. Hetterscheid, N. Tsichlis i Spithas and B. de Bruin, J. Am. Chem. Soc., 2008, 130, 5844-5845.

48 G. V. Koten and K. Vrieze, in Advances in Organometallic Chemistry, ed. F. G. A. Stone and R. West, Academic Press, 1982, vol. 21, pp. 151-239.

49 S. Jiang, T. Y. Zhang, X. Zhang, G. H. Zhang and B. Li, Dalton Trans., 2015, 44, 16708-16712.

50 T. Matsumoto, H.-C. Chang, M. Wakizaka, S. Ueno, A. Kobayashi, A. Nakayama, T. Taketsugu and M. Kato, J. Am. Chem. Soc., 2013, 135, 8646-8654.

51 A. M. Swartz, M. Barra and D. Kuntz, J. Org. Chem., 2004, 69, 3198-3201.

52 Y. Higuchi, H. Ogata, K. Miki, N. Yasuoka and T. Yagi, Structure, 1999, 7, 549-556.

53 T. Krämer, M. Kampa, W. Lubitz, M. van Gastel and F. Neese, ChemBioChem, 2013, 14, 1898-1905.

54 M.-E. Pandelia, H. Ogata and W. Lubitz, ChemPhysChem, 2010, 11, 1127-1140.

55 P. Amara, A. Volbeda, J. C. Fontecilla-Camps and M. J. Field, J. Am. Chem. Soc., 1999, 121, 4468-4477.

56 Y. Nicolet, A. L. de Lacey, X. Vernède, V. M. Fernandez, E. C. Hatchikian and J. C. Fontecilla-Camps, J. Am. Chem. Soc., 2001, 123, 1596-1601.

57 S. Stripp, O. Sanganas, T. Happe and M. Haumann, Biochemistry, 2009, 48, 5042-5049.

58 P. E. M. Siegbahn, J. W. Tye and M. B. Hall, Chem. Rev., 2007, 107, 4414-4435. 